\title{
Rhodoliths holobionts in a changing ocean: host-microbes interactions mediate coralline algae resilience under ocean acidification
}

\author{
Giselle S. Cavalcanti ${ }^{1,2^{*}}$, Priya Shukla², Megan Morris², Bárbara Ribeiro ${ }^{1}$, Mariah Foley², Michael P. Doane²,
} Cristiane C. Thompson ${ }^{1}$, Matthew S. Edwards², Elizabeth A. Dinsdale² and Fabiano L. Thompson ${ }^{1 *}$

\begin{abstract}
Background: Life in the ocean will increasingly have to contend with a complex matrix of concurrent shifts in environmental properties that impact their physiology and control their life histories. Rhodoliths are coralline red algae (Corallinales, Rhodophyta) that are photosynthesizers, calcifiers, and ecosystem engineers and therefore represent important targets for ocean acidification (OA) research. Here, we exposed live rhodoliths to near-future OA conditions to investigate responses in their photosynthetic capacity, calcium carbonate production, and associated microbiome using carbon uptake, decalcification assays, and whole genome shotgun sequencing metagenomic analysis, respectively. The results from our live rhodolith assays were compared to similar manipulations on dead rhodolith (calcareous skeleton) biofilms and water column microbial communities, thereby enabling the assessment of host-microbiome interaction under climate-driven environmental perturbations.

Results: Under high $\mathrm{pCO}_{2}$ conditions, live rhodoliths exhibited positive physiological responses, i.e. increased photosynthetic activity, and no calcium carbonate biomass loss over time. Further, whereas the microbiome associated with live rhodoliths remained stable and resembled a healthy holobiont, the microbial community associated with the water column changed after exposure to elevated $p \mathrm{CO}_{2}$.

Conclusions: Our results suggest that a tightly regulated microbial-host interaction, as evidenced by the stability of the rhodolith microbiome recorded here under OA-like conditions, is important for host resilience to environmental stress. This study extends the scarce comprehension of microbes associated with rhodolith beds and their reaction to increased $p \mathrm{CO}_{2}$, providing a more comprehensive approach to OA studies by assessing the host holobiont.
\end{abstract}

Keywords: Climate change, Coralline crustose algae, Host-microbe interactions, Metagenomics, Ocean acidification, Rhodolith

\section{Background}

Changes in ocean carbonate chemistry driven by increasing anthropogenic carbon dioxide $\left(\mathrm{CO}_{2}\right)$ emissions promote ocean acidification (OA). Increasing ocean $\mathrm{CO}_{2}$ uptake results in the elevation of partial pressure of $\mathrm{CO}_{2}$ $\left(p \mathrm{CO}_{2}\right)$, lower $\mathrm{pH}$ levels, and lower carbonate saturation of seawater, all of which control the calcification process

\footnotetext{
* Correspondence: gscanti@gmail.com; fabianothompson1@gmail.com ${ }^{1}$ Biology Institute, Federal University of Rio de Janeiro (UFRJ), Rio de Janeiro, RJ 21941-599, Brazil
}

Full list of author information is available at the end of the article
$[1,2]$. The OA-induced changes in seawater carbonate chemistry may affect organisms that accrete carbonate as part of their physical structure since precipitating $\mathrm{CaCO}_{3}$ would become less efficient [3-6]. Therefore, OA poses a serious threat to calcifying marine organisms (e.g. corals, coralline algae, mollusks, echinoderms) by affecting their growth and reproduction [7-10]. Coralline algae are considered particularly sensitive to OA since they precipitate high Mg-calcite carbonate skeletons, the most soluble form of $\mathrm{CaCO}_{3}$ [11], which constitute more than $80 \%$ of the dry mass of the thallus [12].

(c) The Author(s). 2018 Open Access This article is distributed under the terms of the Creative Commons Attribution 4.0 International License (http://creativecommons.org/licenses/by/4.0/), which permits unrestricted use, distribution, and 
As both photosynthesizers and calcifiers, coralline algae may respond in multiple ways to ocean acidification. Calcification rates in coralline algae are thought to be directly related to their photosynthetic rates, but it is still not clear how a high- $\mathrm{CO}_{2}$ environment might affect this group of photosynthetic calcifying algae [13]. Elevated $\mathrm{CO}_{2}$ levels might impact calcifying algae by impairing biomineralization, due to decreased seawater carbonate $\left(\mathrm{CO}_{3}{ }^{2-}\right)$ availability as $\mathrm{pH}$ falls; but it also may promote photosynthesis (within tolerance limits), as the availability of bicarbonate $\left(\mathrm{HCO}_{3}{ }^{-}\right)$increases [9]. Indeed, the expected parabolic relationship between declining $\mathrm{pH}$ and coralline algal fitness may explain the varied responses to declining $\mathrm{pH}$ and elevated $p \mathrm{CO}_{2}$ that have been recorded to date [14-23]. To ascertain the extent till which these opposing effects offset each other represents a crucial step in understanding the potential overall impact of OA on crustose coralline algae.

Among coralline algae (Corallinales, Rhodophyta), rhodoliths are the free-living non-geniculate species, which form extensive beds worldwide by accumulating live and dead thalli [24-26]. Rhodolith beds provide a multidimensional structure for organisms to settle, thus increasing biodiversity and acting as a nursery ground [27]. In addition, rhodolith beds produce calcium carbonate and dissolved organic carbon, which support the proliferation of other trophic levels within the ecosystem, including microbes $[28,29]$. The microbes associated with the rhodolith algae are comprised of a diverse assemblage of bacteria, small eukaryotes, and viruses. Collectively, the algae and associated microbes function as an ecological unit termed the holobiont [30, 31]. Rhodoliths support a stable microbiome that maintains an extremely homogenous composition even in specimens that occur $100 \mathrm{~km}$ from each other [28]. However, whether the rhodolith microbiome remains stable under environmental perturbations, such as stressors from ocean acidification, is unknown.

Recent work has focused on the effects of OA and co-occurring environmental changes on coralline algae (e.g. reviewed [13]). However, studies assessing the response of coralline algae-associated microbial communities remain incipient despite the acknowledged role of bacterial communities in algal biology [30, 32-34]. Furthermore, the comprehension of algal-bacterial interactions are key to elucidate processes important for the acclimation of the holobiont to environmental changes [35-38]. For example, changes in the microbial community associated with crustose coralline algae (CCA) and a concomitant reduction in coral larval settlement under OA conditions were previously documented [39]. A second study assessing the microbial communities of calcifying reef taxa (i.e. corals, CCA, foraminifera, sea urchins) found their microbiome remained stable under experimental exposure to reduced $\mathrm{pH}$ seawater but $\mathrm{CCA}$ and foraminifera were sensitive to the combined effects of ocean warming and acidification [40]. Further studies should elucidate the mechanisms through which microbial shifts affect host health and fitness. Nevertheless, the sensitivity of microbial taxa associated with CCA and foraminifera highlight the need for a holobiont centric-approach to assess vulnerability to climate change.

Here, we report the first metagenomic analysis of live rhodoliths, the microbial biofilm that developed on the calcareous skeleton or thalli that was devoid of tissue (subsequently referred to as dead rhodolith), and the surrounding water column exposed to near future OA conditions. We aimed to investigate the influence of increased $p \mathrm{CO}_{2}$ on the physiological and microbiome responses of rhodolith-forming crustose coralline algae under controlled experimental mesocosms. Specifically, rhodolith physiology was measured through photosynthesis and calcification assays, and the stability of its associated microbiome was characterized using whole-genome shotgun metagenomic sequencing analysis. Responses in the live rhodolith microbiomes were compared against those of the dead rhodoliths and water column controls to identify the potential for host-mediated influence on microbiome resilience. We hypothesized that, due to the essential roles that microbiomes play in normal physiological host function and susceptibility to environmental stress, the live rhodoliths would exhibit a stable microbiome under high $p \mathrm{CO}_{2}$ exposure while the algal physiology was not impaired. Our results support the hypothesis that coralline algae rhodoliths harbor a tightly controlled and stable microbiome, important to the holobiont resilience in face of imminent ecological stressors.

\section{Results}

\section{Rhodolith photosynthesis and calcification}

Photosynthetic carbon uptake by live rhodoliths differed between $p \mathrm{CO}_{2}$ treatments at the end of the experiment (Fig. 1a). Live rhodoliths under high $p \mathrm{CO}_{2}$ had higher maximum potential photosynthetic rates $\left(\mathrm{P}_{\max }\right)$, two-fold higher than observed in algae under ambient air. In contrast, the photosynthetic efficiency $(\alpha)$ was not affected by $p \mathrm{CO}_{2}$ treatment.

Rhodolith calcification was not significantly impaired during the experiment. The amount of calcium carbonate was calculated through the decalcification assay and revealed that, over time, live rhodoliths lost tissue, not skeleton (Fig. 1b). The proportion of live tissue (percentage of organic material) on rhodoliths under ambient air and, more markedly, under high $\mathrm{CO}_{2}$ decreased from the start of the experiment (day 1) to the end (day 40). Nevertheless, only one high $\mathrm{CO}_{2}$ mesocosm displayed a statistically significant decline over time $(p=0.008)$. The 


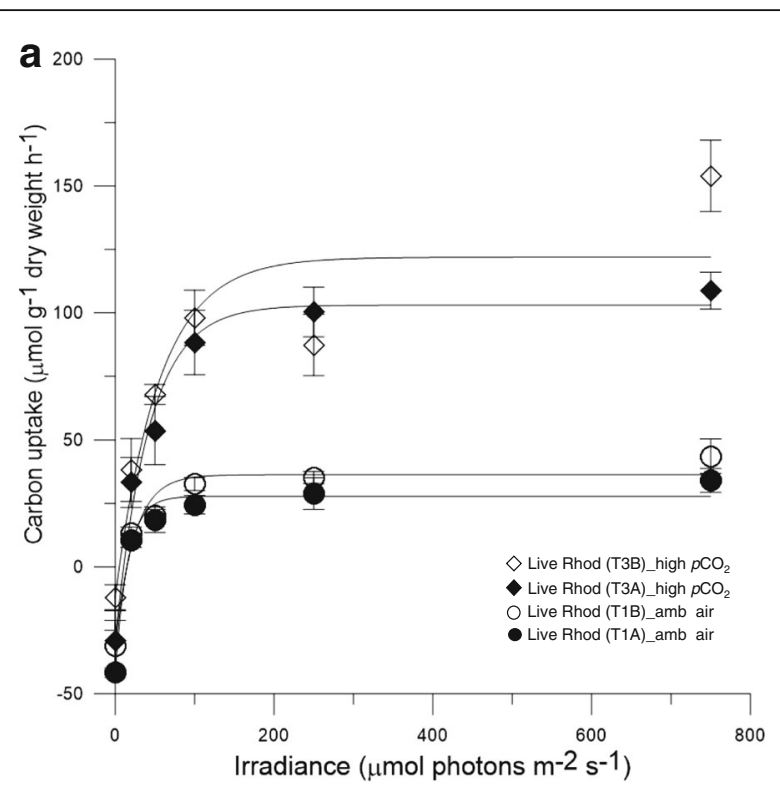

b

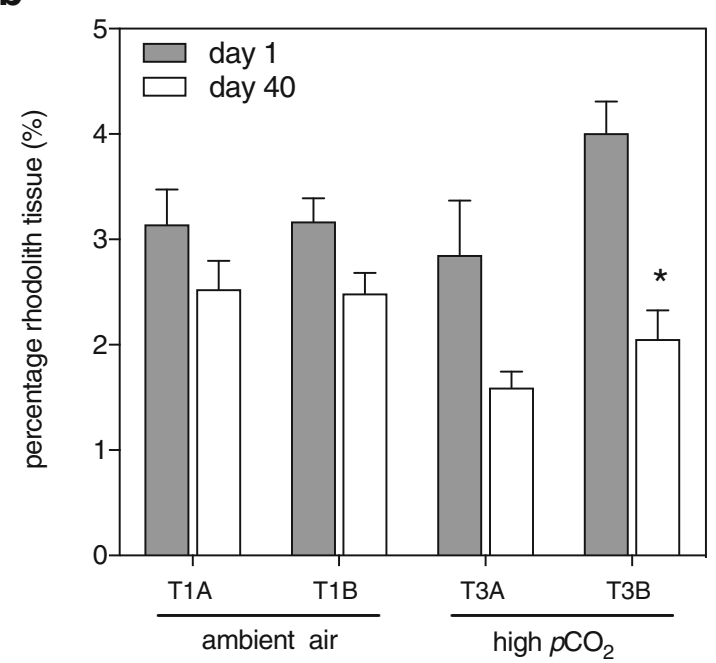

Fig. 1 Rhodolith physiology was not impaired under elevated $p \mathrm{CO}_{2}$. a Photosynthesis, measured as carbon uptake by live rhodolith, under ambient air (tanks 1A and 1B) and high $\mathrm{CO}_{2}$ (Tanks 3A and 3B), at the end of the 40-day experiment. Rhodolith specimens $(n=3$ per mesocosm) were cultured under 6 light levels $(0,25,50,100,250$, and $750 \mu$ mols photons $\mathrm{m}^{-2} \mathrm{~s}^{-1}$ ) for one hour each (in triplicate). Best-fit curves were calculated for each treatment and photosynthetic maximum $\left(P_{\max }\right)$ and photosynthetic efficiency (a) were calculated from these using Platt et al. (1975). b Proportion of live tissue in rhodolith holobionts under ambient air (tanks $1 \mathrm{~A}$ and $1 \mathrm{~B}$ ) and high $\mathrm{CO}_{2}$ (Tanks $3 \mathrm{~A}$ and $3 \mathrm{~B}$ ), measured through decalcification assay, at the beginning (day 1 ) and ending (day 40 ) of the experiment. ${ }^{*}$ ) denotes statistically significant difference over time

percentage of inorganic matter (skeleton) increased $0.65 \%$ for the rhodoliths under ambient air treatment (from 96.85 and $96.82 \%$ at day 1, to $97.47 \%$ and $97.51 \%$ at day 40 for $\mathrm{T} 1 \mathrm{~A}$ and $\mathrm{T} 1 \mathrm{~B}$, respectively) and increased $1.66 \%$ for the rhodoliths under high $\mathrm{CO}_{2}$ treatment (from 97.15 and $95.99 \%$ at day 1, to $98.41 \%$ and $97.94 \%$ at day 40 for $\mathrm{T} 3 \mathrm{~A}$ and $\mathrm{T} 3 \mathrm{~B}$, respectively). Rhodoliths showed a higher percentage of inorganic carbon (calcareous skeleton) in the high $p \mathrm{CO}_{2}$ treatment.

\section{Rhodolith microbiome}

Whole genome sequencing of total DNA extracted from the live rhodolith holobionts, the dead rhodolith biofilm, and the seawater from the holding tanks yielded 28 metagenomic libraries totaling 16.31 million quality reads, with an average of $108,476,267$ bp per metagenome (Additional file 1). The sequenced reads were annotated using the MG-RAST [41]. Subsequent comparison with the NR database from GenBank provided taxonomic annotations for $17 \%$ to $49 \%$ of rhodolith metagenomes and $23 \%$ to $48 \%$ of seawater metagenomes. The function assignments obtained from the SEED database provided metabolic annotations for $19 \%$ to $63 \%$ of rhodolith metagenomes and $29 \%$ to $59 \%$ of seawater metagenomes. Bacteria were the most abundant domain in all metagenomes, with higher average proportions in both seawater $(98.7 \%)$ and dead rhodoliths microbiomes (96.6\%) compared with the live rhodolith holobionts (73.2\%). The Eukaryota and Archaea domains comprised on average $25.0 \%$ and $1.4 \%$, respectively, of live rhodolith metagenomes. Eukaryotes represented $3.0 \%$ of dead rhodolith metagenomes and $0.6 \%$ of seawater metagenomes, while Archaeans comprised only $0.2 \%$ of the sequences from seawater and dead rhodoliths biofilm. Taxonomic similarities in Archaea families and Eukarya classes revealed a stable community composition in the live rhodolith metagenomes (Additional file 2).

The bacterial taxonomy of the live rhodolith microbiomes was stable across time regardless of $p \mathrm{CO}_{2}$ treatments or sampling period (Fig. 2), which can be visualized as all 8 metagenomes taken from the live rhodoliths clustered together on the nMDS plot (Fig. 2b). In comparison, the dead rhodolith biofilm metagenomes displayed a shift during the course of the experiment. The shift in the dead rhodolith microbial community observed during the experiment resembled a biofilm succession, where the Gammaproteobacteria, predominant in day 1 , were partially replaced, by Alphaproteobacteria and Flavobacteria towards the end of the experiment (day 40) (Fig. 2a). Over the 40 days experiment, the microbiome that formed on the dead rhodoliths showed a decrease in the relative abundance of gram-negative marine copiotrophic Gammaproteobacteria families Pseudoalteromonadaceae (-84.23\%), Alteramonadaceae (-69.13\%), Colwelliaceae (-89.66\%), Pseudomonadaceae (-41.32\%), Shewanellaceae (-66.76\%), Vibrionaceae (-55.50\%), Oceanospirillaceae (-64.02\%). After the 40 days exposure to high $p \mathrm{CO}_{2}$, an increase was observed in the relative abundance of the Alphaproteobacteria families Rhodobacteraceae (+117.41\%), Hyphomonadaceae (+261.95\%), 


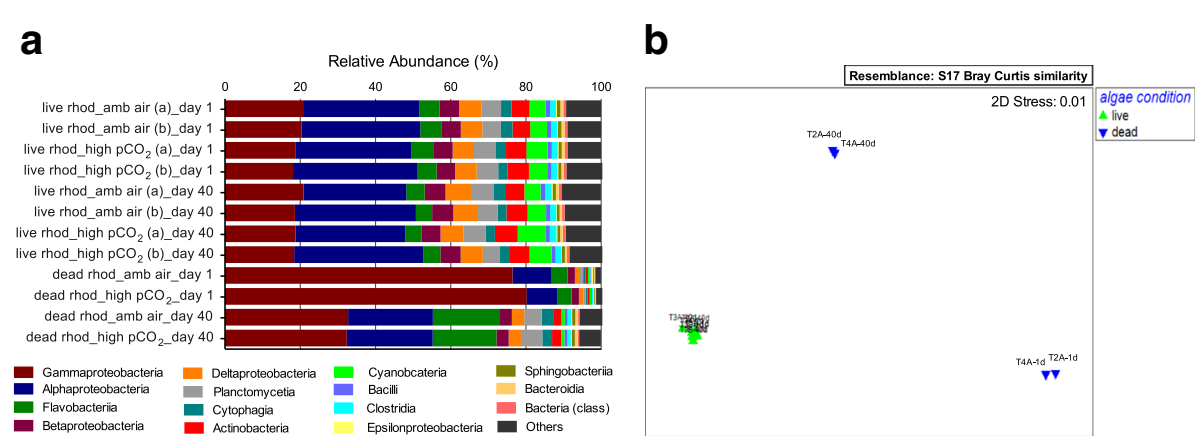

Fig. 2 Rhodolith microbiome was stable under elevated $p \mathrm{CO}_{2}$. a Relative abundance of the 15 most abundant bacterial classes in dead (calcareous skeleton biofilm) and live rhodolith metagenomes, under ambient air and high $\mathrm{CO}_{2}$ treatments. $\mathbf{b} \mathrm{MDS}$ plot for the relative abundance of rhodolith bacterial taxonomic similarities by class contribution (Bray Curtis similarity). Algae condition was the grouping variable, represented by green triangle for live rhodolith (T1A, T1B - live rhod_amb air; T3A, T3B - live rhod_high $\mathrm{CO}_{2}$ ) with no effect from time (1 day versus 40 days) or p $\mathrm{CO}_{2}$ level (ambient air versus high $\mathrm{CO}_{2}$ ) variables; and blue triangle for dead rhodolith (T2A - dead rhod_ high $\mathrm{CO}_{2} ; \mathrm{T} 4 \mathrm{~A}$ - dead rhod_amb air), at the beginning (day 1) and ending (day 40) of the experiment

Phyllobacteriaceae (+372.82\%), Rhizobiaceae (+311.97\%), Rhodospirillacecae $(+249.17 \%)$ as well as in the Cytophaga-Flavobacterium-Bacteroides (CFB) families Cytophagaceae (+327.82\%), Flavobacteriaceae (+334.03\%), Bacteroidaceae $(+249.17 \%)$ (Additional file 3$)$.

The live rhodoliths showed a stable microbiome that did not change with $p \mathrm{CO}_{2}$ levels or time (Fig. 2). To compare the amount of change in bacterial taxonomy that occurred over time, we calculated the mean change in Bray-Curtis similarity among each of the rhodolith thallus treatments (i.e. live and dead rhodoliths), and each of the two seawater locations (i.e. water column over the live and dead rhodoliths) (Fig. 3). Changes in bacterial communities between day 1 and day 40 were statistically significant between live and dead treatments (2-way ANOVA, $p=3.05 \times 10^{-3}$ ), but not significant between location (tank seawater versus rhodolith thalli) (2-way ANOVA, $p=1.07 \times 10^{-1}$ ). However, the algal treatment factor (live versus dead) interacted with location (tank seawater versus rhodoliths thalli) (2-way ANOVA, $p=8.12 \times 10^{-3}$ ). Thus, the larger variation (statistically significant) in bacterial communities observed in the seawater holding tank and dead rhodolith biofilm throughout the experiment was mainly driven by the comparison with the stable microbiome observed in live rhodoliths (Fig. 3). Tukey's post hoc tests revealed that temporal changes in the bacterial communities associated with the live rhodoliths were significantly different from those associated with the dead rhodoliths $\left(p=5.34 \times 10^{-3}\right)$, as well as with the water column over both the dead rhodoliths $(p=1.55 \times$ $\left.10^{-2}\right)$, and live rhodoliths $\left(p=2.76 \times 10^{-2}\right)$. No temporal differences were observed among pairs of the other three treatments. Thus, the bacterial communities associated with live rhodoliths were similar over the course of the experiment, whereas significant changes in community structure were observed with the dead rhodoliths and both seawater column treatments (Fig. 3).

Multiple group analysis comparing rhodolith microbiome between algae condition (live versus dead) and $p \mathrm{CO}_{2}$ levels identified Cyanobacteria $\left(p=3.81 \times 10^{-6}\right)$, Actinobacteria $\left(p=3.79 \times 10^{-3}\right), \quad$ Deltaproteobacteria $\quad\left(p=1.30 \times 10^{-2}\right)$, Betaproteobacteria $\left(p=1.62 \times 10^{-2}\right)$, Clostridia $(p=1.77 \times$ $\left.10^{-2}\right)$, and Gammaproteobacteria $\left(p=2.12 \times 10^{-2}\right)$ as bacterial classes with average abundance above $1.0 \%$ that were significantly different (ANOVA $p$-value $<0.05$ ).

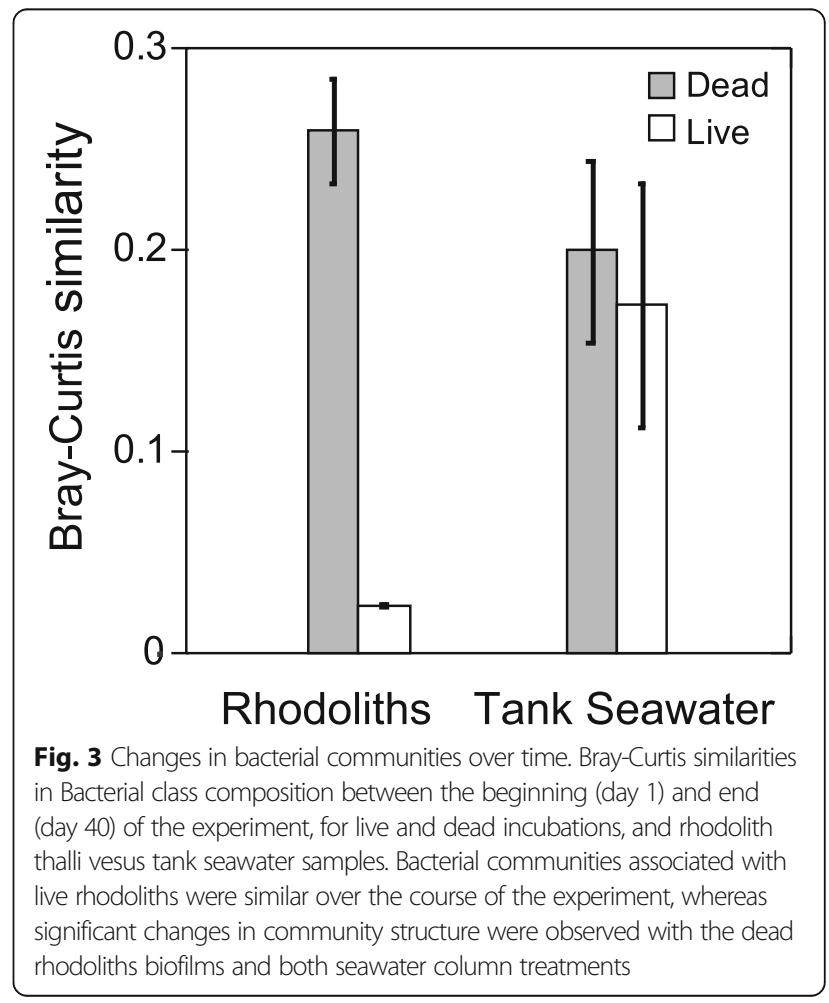




\section{Microbial diversity in the seawater holding tanks}

Microbial diversity within seawater holding tanks varied through time and was affected by $p \mathrm{CO}_{2}$, regardless of the presence or absence of live rhodoliths (Fig. 4). Alphaproteobacteria (43.92\%), Gammaproteobacteria (28.71\%), Flavobacteria (10.49\%), Betaproteobacteria (4.10\%), Planctomycetia (2.38\%), Actinobacteria (1.85\%), Deltaproteobacteria (1.33\%) were the classes with average abundance above $1.0 \%$ that contributed to this variation (Fig. 4a). When analyzing seawater metagenomes, the rhodolith condition (live versus dead) was a poor predictor of microbial community structure. In contrast, an effect of the different $p \mathrm{CO}_{2}$ treatments was observed, where holding tanks kept under high $\mathrm{CO}_{2}$ were closely related in the MDS plot (Fig. 4b). The microbial community within the high $p \mathrm{CO}_{2}$ holding tanks from both live and dead rhodoliths (dark blue triangles in Fig. 4b) showed the same trajectory on the MDS plot. In particular, the Alphaproteobacteria contribution decreased from over $60 \%$ of the community on day 1 to about $20 \%$ of the community on day 40 in both water columns high $p \mathrm{CO}_{2}$ treatments (Fig. 4a). Taxonomic differences among the water profiles across the experiment (time grouping variable) were driven by the classes Flavobacteria $\left(p=8.82 \times 10^{-3}\right)$, Deltaproteobacteria $\left(p=1.06 \times 10^{-2}\right)$, and Alphaproteobacteria $\left(p=1.87 \times 10^{-2}\right)($ ANOVA $p$-value $<0.05)$.

\section{Functional profile of rhodoliths and seawater}

Predicted metabolic similarities in rhodolith and water metagenomes under combined treatments (algae condition, $p \mathrm{CO}_{2}$, time) revealed three clusters in the PCA plot: live rhodoliths, biofilm on dead rhodoliths, and holding tank water (Fig. 5). No statistically significant differences were found between $p \mathrm{CO}_{2}$ levels within both dead and live treatments for either rhodolith holobionts or seawater column (two-group comparisons) (Additional file 4).

The dead rhodolith microbiome displayed higher mean relative frequencies assigned to metabolic biofilm formation when compared to seawater and live rhodoliths, including carbohydrates [aminosugars $\left(p=2.57 \times 10^{-6}\right)$, polysaccharides $\left(p=5.25 \times 10^{-6}\right)$, di- and oligosaccharides $\left(p=3.70 \times 10^{-5}\right)$, organic acids $\left.\left(p=2.55 \times 10^{-2}\right)\right]$; cell wall and capsule $\left(p=4.03 \times 10^{-6}\right)$; iron acquisition and metabolism $\left(p=4.24 \times 10^{-2}\right)$; membrane transport [protein secretion system, Type III $\left(p=5.45 \times 10^{-3}\right)$, membrane transport $\left.\left(p=1.36 \times 10^{-2}\right)\right]$, motility and chemotaxis [flagellar motility $\left(p=1.07 \times 10^{-3}\right)$, motility and chemotaxis $\left.\left(p=2.56 \times 10^{-3}\right)\right]$ and stress response $\left(p=4.60 \times 10^{-2}\right)$.

In comparison with dead rhodolith and seawater, live rhodolith metagenomes under both ambient air and high $\mathrm{CO}_{2}$ conditions showed increased proportion of sequences associated with the metabolism of nitrogen $\left(p=1.26 \times 10^{-6}\right)$, protein [protein biosynthesis $\left(p=3.89 \times 10^{-3}\right)$, protein folding $\left.\left(p=9.11 \times 10^{-3}\right)\right]$, RNA [transcription $\left(p=2.50 \times 10^{-8}\right)$, RNA metabolism $\left(p=7.07 \times 10^{-8}\right)$ ] and sulfur [inorganic sulfur assimilation $\left(p=1.21 \times 10^{-8}\right)$, organic sulfur assimilation $(p=1.20 \times$ $\left.10^{-4}\right)$ ], as well as in the photosynthesis [electron transport and photophosphorylation $\left(p=7.16 \times 10^{-19}\right)$, light-harvesting complexes $\left.\left(p=1.76 \times 10^{-13}\right)\right]$ and respiration $[$ respiration $\left(p=4.95 \times 10^{-7}\right)$, ATP synthases $\left(p=1.78 \times 10^{-5}\right)$, electron donating reactions $\left(p=2.29 \times 10^{-2}\right)$.

\section{Discussion}

The results of this experimental study showed that the microbial community structure in the seawater and the dead rhodoliths biofilm changed during the course of the experiment, while the live rhodolith microbiome remained stable. Further, the algae photosynthetic capacity increased after exposure to high $p \mathrm{CO}_{2}$. The

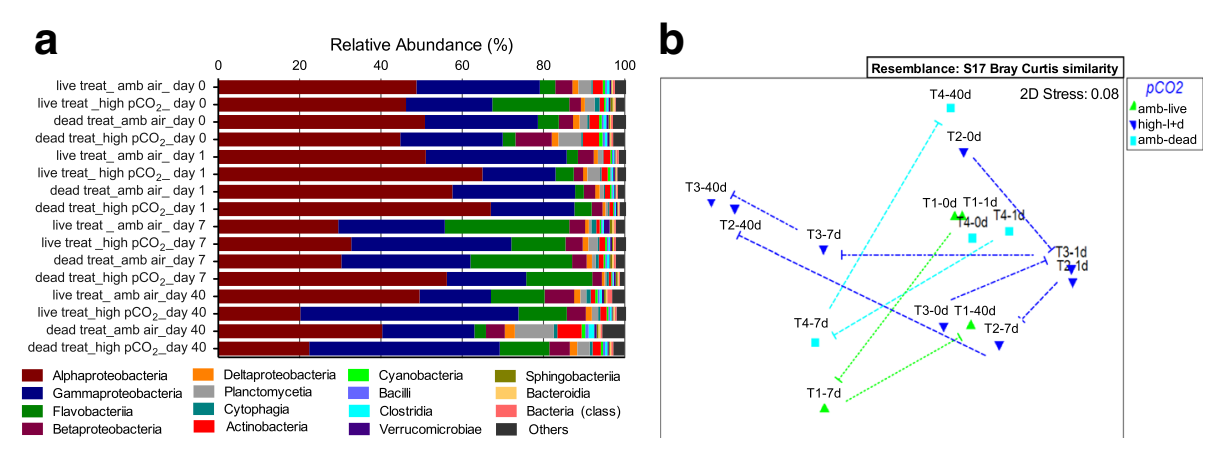

Fig. 4 Water column microbial communities shifted under elevated $p \mathrm{CO}_{2}$. a Relative abundance of the 15 most abundant bacteria classes in seawater metagenomes. $\mathbf{b}$ MDS plot for the relative abundance of the seawater holding tanks taxonomic similarities by class contribution (Bray-Curtis similarity). Seawater metagenomes were represented by $\mathrm{pCO}_{2}$ treatment, green triangle for live rhodolith in ambient air ( $\mathrm{T} 1$ - tank 1), blue triangle for high $p \mathrm{CO}_{2}$ treatments - both calcareous skeleton (T2 - tank 2) and live rhodolith (T3 - tank 3), light blue square for dead rhodolith (calcareous skeleton in ambient air (T4 - tank 4). The respective color dashed lines connect the temporal sequence of each specific $p \mathrm{CO}_{2}$ treatment in the plot. Water metagenomes from each one of the four tanks were sequenced from days 0, 1, 7, 40 (0d, 1d, 7d, 40d, respectively) 


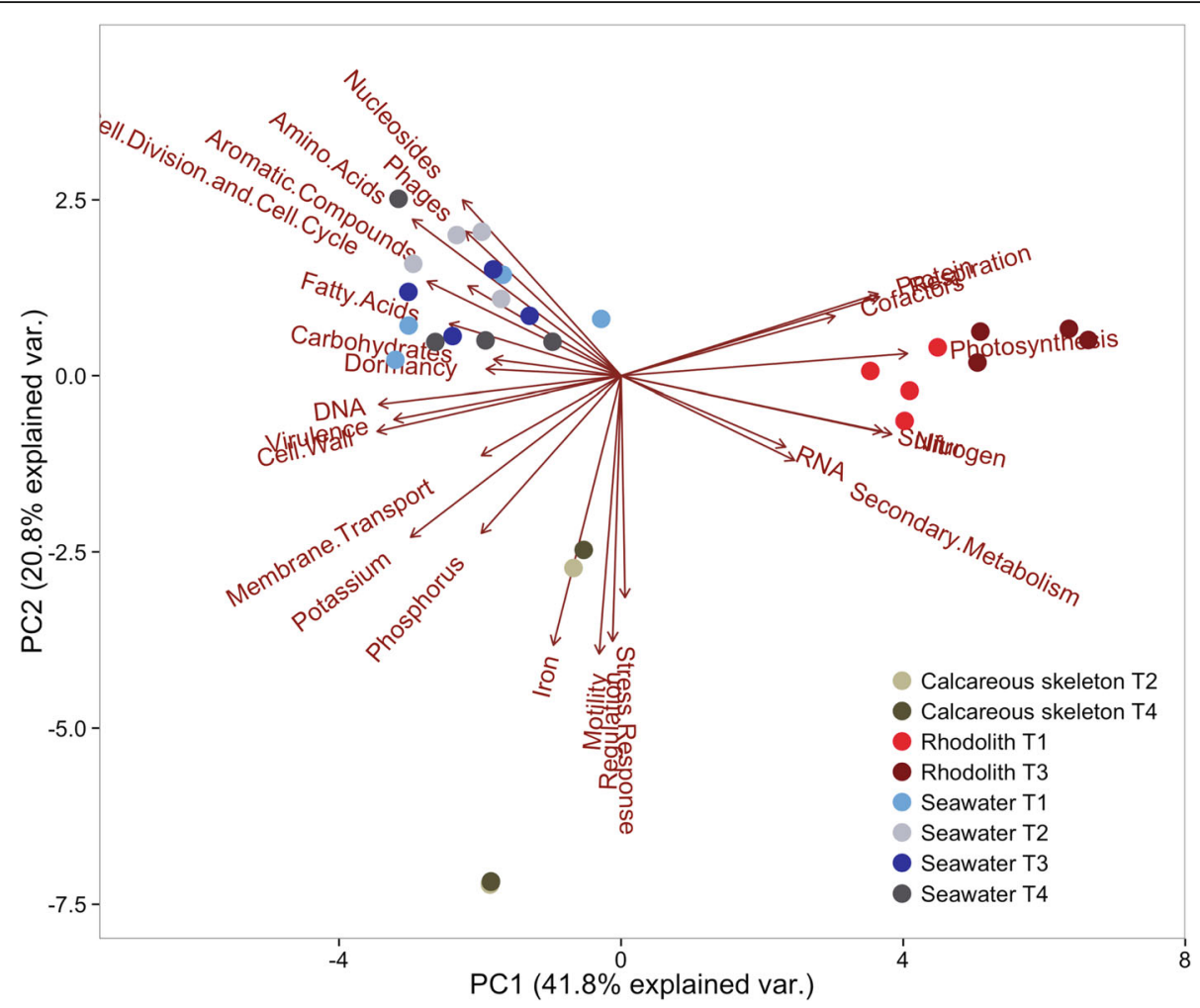

Fig. 5 Functional analysis grouped the microbial communities by live rhodolith, dead rhodolith, or seawater. Principal component analysis (PCA) depicting the correlations between predictor variables (SEED database level 1 subsystems - red arrows) and the metabolic similarity in rhodolith (live and dead) and seawater metagenomes for all treatments (28 metagenomes) during the experiment. The length of the arrow represents how well the parameter explains the distribution of the data. PCA grouping live rhodolith microbiome under ambient air (red circle; T1 - Tank 1) and high $\mathrm{CO}_{2}$ (dark red circle; T3 - Tank 3); dead rhodolith biofilm under ambient air (beige circle; T4 - Tank 4) and high $\mathrm{CO}_{2}$ (brown circle; T2 - Tank 2); and seawater metagenomes under four combined treatments: live algae, ambient air (light blue circle; seawater T1 - Tank 1), live algae, high $\mathrm{CO}_{2}$ (blue circle; seawater T3 - Tank 3), dead rhodolith, ambient air (gray circle; seawater T4 - Tank 4), dead rhodolith, high $\mathrm{CO}_{2}$ (dark gray; seawater T2 - Tank 2) by functional contribution in first level of hierarchy (level 1)

inorganic carbon rates (percentage of calcareous skeleton) were higher in rhodoliths under high $p \mathrm{CO}_{2}$ treatment, but organic content (live tissue) was lower, suggesting that the excess energy from photosynthesis went towards deposition of $\mathrm{CaCO}_{3}$ rather than growth.

\section{Enhanced photosynthetic performance offsets rhodolith calcification under enriched $\mathrm{CO}_{2}$}

Consistently elevated rates of carbon uptake during photosynthesis were observed in rhodoliths under high $p \mathrm{CO}_{2}$, as indicated by a higher $\mathrm{P}_{\max }$, compared with observations for rhodoliths under ambient air treatment. Photosynthetic efficiency $(\alpha)$ was unaltered regardless of $p \mathrm{CO}_{2}$. A significant increase in sequences associated with photosynthetic activity was observed among live rhodolith metagenomes compared to water column and dead rhodolith biofilm. Accordingly, the proportion of sequences assigned to photosynthesis metabolism was $24.31 \%$ higher under elevated $\mathrm{CO}_{2}$ compared to the ambient air live rhodolith metagenomes. Photosynthesis draws carbon $\left(\mathrm{CO}_{2}\right.$ or bicarbonate) from total $C_{I}$ [42], whereas calcification takes up inorganic carbon and releases $\mathrm{CO}_{2}$. Calcification is an energy-demanding process and photosynthesis can provide the energy needed to support the precipitation of carbonate skeletons. In our study, the inorganic carbon rates (percentage of calcareous skeleton) were higher in the rhodolith under high $p \mathrm{CO}_{2}$ treatment compared to rhodolith under ambient air treatment, but organic content was lower. Therefore, it is possible that more inorganic carbon was allocated to deposition of $\mathrm{CaCO}_{3}$, but at the cost of growth.

The research on OA in mesocosms poses challenges due to the constraints in fully reproducing field conditions in the laboratory. Coralline algae have shown strong species-specific responses to elevated $p \mathrm{CO}_{2}$, where two closely related species in the same genus presented disparate responses [43], or variable responses could be recorded between two studies on the same species [44]. However, the variable responses of coralline algae could be driven by the timescale of the physiological measurements, and the acclimation period or the time of the year experiments were done 
[45]. Our results and the evidence from short-term studies confirm the stimulation of photosynthesis in coralline algae with increased $\mathrm{CO}_{2}$ availability.

Photosynthesis rates and the surrounding concentration of inorganic carbon are related to calcification rates in coralline algae. Similarly, calcification can stimulate algal photosynthesis, if it acts as a carbon concentration mechanism, as proposed previously [46]. Briefly, according to the "trans calcification" mechanism, an external carbonic anhydrase converts bicarbonate ions to $\mathrm{CO}_{2}$ for photosynthesis, which, in turn, releases the carbonate $\left(\mathrm{CO}_{3}{ }^{2-}\right)$ used in algal calcification [46]. Photosynthetic activity in macroalgae leads to a $\mathrm{pH}$ increase in the intercellular spaces along in the diffusion boundary layer. The persistent diffusion boundary layer at the surface of coralline algae creates a $\mathrm{pH}$ microenvironment very different from the mainstream seawater [47, 48] and the stability in the microbiome with increasing $p \mathrm{CO}_{2}$ confirms the control the algae exert on the boundary layer. As rhodoliths precipitate $\mathrm{CaCO}_{3}$ in their cell walls, the increase in $\mathrm{pH}$ shifts the equilibrium toward an increase in $\mathrm{CO}_{3}{ }^{2-}$ concentration $[49,50]$, which promotes precipitation of $\mathrm{CaCO}_{3}$. Thus, the positive effect of photosynthesis on calcification to a certain extent could offset $\mathrm{CaCO}_{3}$ dissolution in calcifying algae in response to increased $p \mathrm{CO}_{2}$ [49-51]. In the rhodoliths assessed in our study, the increase in photosynthesis may have supported increased calcium carbonate production.

Previous studies have demonstrated a parabolic response in coralline algae physiology to $\mathrm{pH}$ and $p \mathrm{CO}_{2}$ $[14,18,23]$. Yet, most long-term experimental studies show a decrease in calcification and enhanced dissolution in calcifying species under elevated $\mathrm{CO}_{2}$ concentrations [7, 9, 22, 44, 52]. Additionally, as the thermal stress is known to exacerbate the adverse effect of OA on algal physiology $[15,35,44,53,54]$, in the climate-change scenario, where $\mathrm{CO}_{2}$ and temperatures are elevated, the photosynthesis-calcification metabolic processes in calcifying macroalgae might become uncoupled [49]. However, more complete mechanistic understanding of the complex metabolic links between inorganic carbon uptake pathways, photosynthesis, and calcification in coralline algae is still necessary to better predict the physiological limits of these important autotrophs to climate change stressors.

\section{Rhodolith microbiome stability is crucial to holobiont resilience}

Rhodolith function is intimately linked to the composition and structure of their associated microbiome. Due to their diverse metabolic traits, microorganisms play important roles in macroalgae physiology, as suggested for instance, in the biomineralization process
[28]. When considering the phenotypic plasticity of coralline algae to changing environments, the microbiome offers significant but often underappreciated potential. Microbial symbionts can promptly respond to changing environmental conditions, offering a powerful mechanism for acclimatization [55]. However, instabilities in host-microbe interactions can have significant functional consequences for the holobiont physiology and susceptibility to environmental stressors. Healthy hosts normally possess relatively stable microbiomes, where the host-microbes normal regulation leads to beneficial microbiome configurations [56]. Here, we observed a tightly controlled and stable rhodolith microbiome during elevated $p \mathrm{CO}_{2}$ conditions, resembling a healthy holobiont.

Nevertheless, our experimental design assessed the rhodolith holobiont response to a single predicted climate change stressor. It is possible that the single stress applied here was within the algae physiologic tolerance limits, i.e. below the organismal vertices curve response, and therefore was not sufficient to cause dysbiosis. We hypothesize that the unbalanced tradeoff between photosynthesis and calcification in coralline algae under environmental stress occurs concomitantly with the disturbance of the algae microbiome. For example, combined stressors such as high temperature and high $p \mathrm{CO}_{2}$ could impair host physiology disrupting beneficial host-microbiome interactions (Fig. 6).

Metagenomic analysis provides structural and putative functional information of the host-microbial interactions under study. Future studies using metatranscriptomic analyses that focus on gene expression of active members of microbial communities might reveal microbial responses to rapid environmental change, thereby linking structural shifts to community function [57]. Still, valid predictions of coralline algae rhodolith response to ocean change rely on bridging gaps between diverse omics approaches and earth system science. The development of an improved understanding of coralline algae ecophysiology, considering the interactions between algae and associated bacteria, is key to assess environmental effects on the holobiont. Our study provides a relevant step in this direction.

\section{Conclusions}

OA poses an ever-increasing threat to the ecologic balance and stability of rhodolith bed systems via differential impacts on coralline algae physiology. Rhodolith widespread distribution hints at the resilience of this algal group that remained chief components of benthic marine communities through considerable environment fluctuations (i.e. temperature, light) over geologic times [58]. Whole genome shotgun sequencing performed here on a variety of rhodolith bed constituents revealed a 


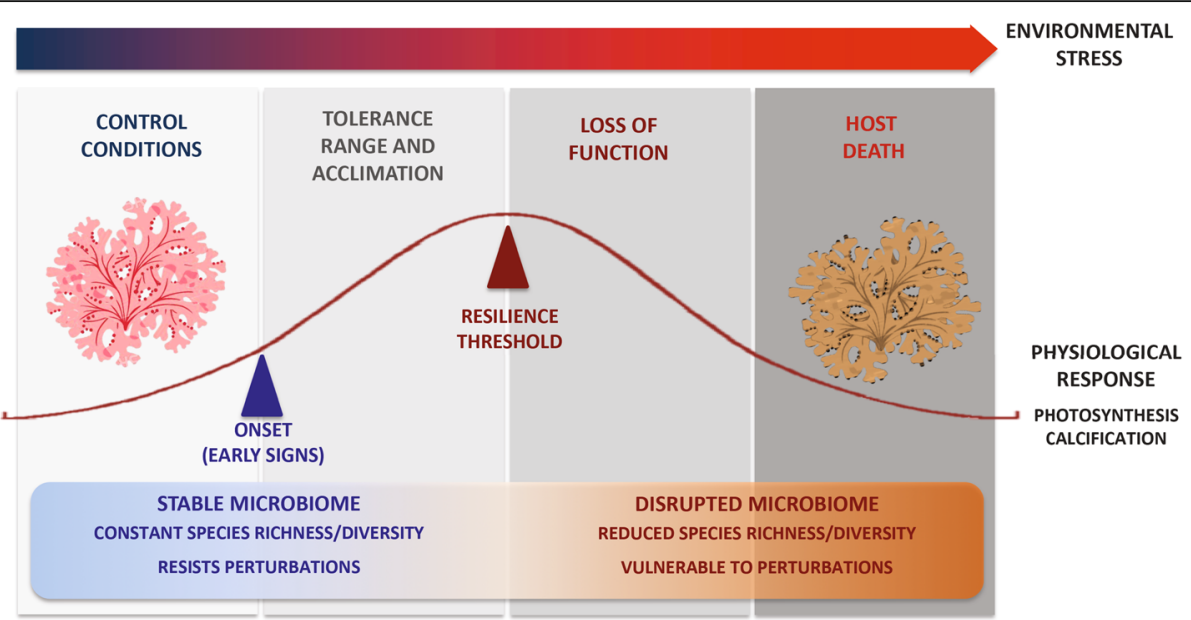

Fig. 6 Conceptual overview of the expected parabolic relationship between climate change stressors and rhodolith holobiont fitness. Under normal conditions, healthy rhodoliths possess stable microbiomes, important to the holobiont function. However, beyond thresholds of algal physiological tolerance to climate change stressors, the disruption of positive host-microbiome interactions occurs, detrimentally affecting the holobiont fitness

stable live rhodolith microbiome still thriving under elevated $p \mathrm{CO}_{2}$ conditions. In contrast, microbial shifts in the seawater column and in the coralline skeleton biofilm were observed. These findings reinforce the existence of a close host-microbe functional entity, where the metabolic crosstalk within the rhodolith as a holobiont could be exerting reciprocal influence over the associated microbiome. Depicting the algal associated microbial diversity and function is crucial to improve our comprehension of processes important for the holobiont resilience under environmental changes.

\section{Methods}

\section{Sample collection and experimental design}

Rhodoliths were collected at a depth of 10-12 m at Avalon harbor $\left(33.3477^{\circ} \mathrm{N}, 118.3246^{\circ} \mathrm{W}\right)$, Catalina Island, California, USA in April 2014. The morphologic features of Catalina Island rhodoliths are consistent with the species Sporolithon australe [59]. Rhodoliths were collected by SCUBA divers and transferred to a laboratory holding tank at USC Marine Science Center (Catalina Island, CA, USA) filled with cycling surrounding seawater at the same natural conditions (temperature and nutrients) for a period of two days. Specimens were then transferred in dark coolers to the San Diego State University Coastal Marine Institute Laboratory (CMIL) (San Diego, $\mathrm{CA})$. Once at the CMIL, rhodoliths were sorted to remove epibionts and associated fauna and then acclimated in incubation mesocosms with recirculating seawater collected off Scripps pier (San Diego, CA). Due to the constraints of collecting representative amounts of dead thalli in the field, the dead rhodoliths (calcareous skeleton) were obtained by sacrificing a subset of the live rhodoliths by drying them at $90{ }^{\circ} \mathrm{C}$ for $96 \mathrm{~h}$ and then bleaching them in sodium hypochlorite solution for $2 \mathrm{~h}$. This treatment aimed to remove any algal live tissue and native associated microbes. The dead rhodoliths (calcareous skeleton) followed a 10-day period of acclimation on the control experimental conditions prior to the beginning of the experiment, in order to provide an initial colonization period for biofilm formation on the clean dead rhodolith surface.

The experimental setup was performed, with few modifications, following Brown [60]. Briefly, the experimental design incorporated two different algae treatments (live rhodoliths and calcareous skeleton from dead rhodoliths) and $p \mathrm{CO}_{2}$ at nearly present (ambient air) or predicted future (high $p \mathrm{CO}_{2}$ ) conditions, in duplicate mesocosms. Approximately $500 \mathrm{~g}$ of live and dead rhodoliths were placed in separated 18.5 $\mathrm{L}$ acrylic mesocosm tanks: tanks $1 \mathrm{~A}$ and $1 \mathrm{~B}$ for live rhodolith, ambient air treatment; tanks $2 \mathrm{~A}$ and 2B for dead rhodolith, high $\mathrm{CO}_{2}$ treatment; tanks $3 \mathrm{~A}$ and $3 \mathrm{~B}$ for live rhodolith, high $\mathrm{CO}_{2}$ treatment; tanks $4 \mathrm{~A}$ and $4 \mathrm{~B}$ for dead rhodolith, ambient air treatment $(n=8$ total). Every two mesocosms were connected to one of four $400 \mathrm{~L}$ seawater holding tanks $(n=2$ mesocosms per large holding tank) in a recirculating system. The large holding tanks were used to maintain a stable $p \mathrm{CO}_{2}$ levels during the experiment, which is not possible to achieve by injecting the $\mathrm{CO}_{2}$ into the smaller mesocosm $[35,54]$. It must be noted that this logistic constraint associated with our seawater system required that the duplicate mesocosms for each treatment were cultured receiving the water supply of a single large holding tank (i.e., duplicated mesocosms and seawater holding tanks could not be independently replicated). Despite the well-known 
problems of interpreting data based on pseudoreplicated technical samples [61], we point out that this is not uncommon in climate change mesocosm studies $[62,63]$ and relevant measurements in our study assessed the biological replicates of individual holobionts.

\section{Monitoring of the carbonate system}

Seawater $p \mathrm{CO}_{2}$ levels within each large holding tank were adjusted to either ambient air (ca $500 \mu \mathrm{atm}$ ) by bubbling ambient air (the average yearly $p \mathrm{CO}_{2}$ values observed within the Southern California coast [60]); or high $p \mathrm{CO}_{2}$ (ca 1,500 $\mu \mathrm{atm})$ by bubbling a certified $\mathrm{CO}_{2}$ mixture $(1,485 \mathrm{ppm}$ $p \mathrm{CO}_{2}$, Praxair San Diego) into the large holding tanks. The predicted increases in seawater $p \mathrm{CO}_{2}$ (Intergovernmental Panel on Climate Change 2007) are based on models for the open-ocean where values are expected to track atmospheric concentrations, and therefore they may not apply to coastal ecosystems where these values are much more dynamic (e.g., [64]). Along the southern coast of California, USA, $\mathrm{pH}$ values can vary by $0.2-0.4 \mathrm{pH}$ units over the course of a single day [64], naturally exposing organisms to lower $\mathrm{pH}$ values compared to organisms in less variable environments like the open ocean. To ensure $p \mathrm{CO}_{2}$ levels remained at the desired levels, seawater samples were taken daily from the large holding tanks and analyzed using potentiometric titration to determine total alkalinity $\left(\mathrm{A}_{\mathrm{T}}\right)$ and total inorganic carbon $\left(\mathrm{C}_{\mathrm{I}}\right)$ [65]. The titration system consisted of a Metrohm 765 Dosimat titrator and Orion $920 \mathrm{~A} \mathrm{pH}$ meter. $\mathrm{C}_{\mathrm{I}}$ and $\mathrm{A}_{\mathrm{T}}$ could then be entered into the CO2Sys software (http://cdiac.ornl.gov/ftp/co2sys/) to calculate $\mathrm{pH}$ and $p \mathrm{CO}_{2}$ at a constant temperature and salinity [66] (Additional file 5).

Temperature in the holding tanks was maintained at $15{ }^{\circ} \mathrm{C}$ and controlled using aquarium chillers. Light above the mesocosms was provided by full spectrum fluorescent bulbs set on a 12:12 cycle, with light levels set at $\sim 250-300$ photons $\left(\mu \mathrm{mol} \mathrm{m} \mathrm{m}^{-2} \mathrm{~s}^{-1}\right)$, according to previous descriptions of the conditions within Catalina Island rhodoliths beds [67].

\section{Rhodolith physiology}

To determine the effects of elevated $p \mathrm{CO}_{2}$ on rhodolith holobiont photosynthesis, photosynthetic carbon uptake was measured at the end of the 40-day experiment. Live algae from two $p \mathrm{CO}_{2}$ levels (500 $\mu \mathrm{atm}$ and $\left.1500 \mu \mathrm{atm}\right)$ treatments were measured separately over four consecutive days (for both duplicates mesocosms tanks A and B). On each day, $500 \mathrm{~mL}$ BOD bottles were filled with seawater taken from the mesocosm being measured, sealed and stored in the dark within a temperature-controlled room, set to $15{ }^{\circ} \mathrm{C}$. A separate water sample was taken from the large holding tanks to determine starting $\mathrm{C}_{\mathrm{I}}$ for each treatment. Concurrently, three separate rhodolith specimens ( $\sim 0.7 \mathrm{~g}$ wet weight) were taken from the mesocosm being evaluated. Each rhodolith specimen was patted dry, weighed and placed into a BOD bottle. These bottles were then placed upright in separate water baths within the temperature-controlled room and photosynthetic carbon uptake by the algae was measured under six irradiances $(0,25,50,100,250$, and 750 photons ( $\mu \mathrm{mols}$ $\left.\mathrm{m}^{-2} \mathrm{~s}^{-1}\right)$ ) for one hour each. Light was provided by full-spectrum compact fluorescent bulbs hung directly above the bottles and light levels were adjusted either by moving the bulb closer to the bottles, or through window tinting of different shading properties until reaching the desired irradiance as measured with a photometer. To reduce the formation of boundary layers, magnetic stirring bars were placed into each bottle. After one hour, the rhodoliths were removed and the $C_{I}$ within the bottles was measured using potentiometric titration as described above. Carbon uptake was calculated as the difference between $C_{I}$ at the end of one hour versus the treatment's starting $\mathrm{C}_{\mathrm{I}}$ and standardized to the weight of the rhodolith. The rhodolith specimens were transferred to new bottles and the irradiance was increased to the next level. For each mesocosm, the carbon uptake at each light level was plotted and fit as in Platt [68]. From these best-fit lines, the maximum rate of photosynthesis $\left(\mathrm{P}_{\max }\right)$ and the photosynthetic efficiency $(\alpha)$ of each treatment were calculated.

Calcium carbonate loss was calculated on live rhodoliths only, by comparing the proportion of live tissue present on a subset of rhodoliths at the start of the experiment (day 1) and again at the end (day 40), according to Price [69]. To conduct the comparison, approximately, $0.3 \mathrm{~g}$ of rhodolith (the approximated weight of $1 \mathrm{~cm}^{2}$ diameter rhodolith individual) sampled at the beginning and end of the experiment, under both ambient air and high $\mathrm{CO}_{2}$ conditions, were weighed in triplicate and decalcified using formic acid. The rhodoliths were oven dried and weighed at the start and end of the decalcifying process, the mass difference after the removal of calcium carbonate skeleton was considered the proportion of flesh tissue in each sample. The amount of inorganic carbon (calcareous skeleton) was calculated as the total weight minus weight of organic material. The percentage (\%) of inorganic material was calculated as (weight of inorganic carbon/total weight $\times 100$ ). Student's T-test was used to compare the proportion of tissue in the rhodoliths at the start (day 1) and end (day 40) of the experiment.

\section{DNA extraction and construction of metagenomic libraries}

At day 0 , day1, and day 7 of experiment two 4 L seawater samples from each large holding tank $(n=4)$ were collected and filtered using Sterivex filters 
$(0.22 \mu \mathrm{m})$, the holding tanks are independent of each other. Microbial DNA extraction was performed using a modified column purification protocol (Nucleospin Tissue, Macherey-Nagel, Dueren, Germany) with proteinase $\mathrm{K}$ (final concentration $0.2 \mu \mathrm{g} / \mathrm{mL}$ ), followed by incubation at $55{ }^{\circ} \mathrm{C}$ with gentle agitation overnight. By the end of the experiment (day 40), approximately 60-80 L of water from each large holding tank were collected and processed through tangential flow filters (TFFs). The filtrate was concentrated to around $500 \mathrm{ml}$ on a $100 \mathrm{kDa}$ TFF, and then passed through $0.22 \mu \mathrm{m}$ Sterivex filters (Millipore, Inc) using a $60 \mathrm{ml}$ syringe.

Rhodolith gDNA extraction was performed using multiple whole rhodolith individuals $\left(\sim 1 \mathrm{~cm}^{2}\right.$ diameter) from each duplicate mesocosm (A and $\mathrm{B}$ ) under both $p \mathrm{CO}_{2}$ levels (ambient air and high $\mathrm{CO}_{2}$ ) for the live rhodolith treatment; and one mesocosm (A) of both $p \mathrm{CO}_{2}$ levels (ambient air and high $\mathrm{CO}_{2}$ ) for the dead rhodolith treatment. The samples were collected at day 1 and day 40, i.e., the beginning and end of the experiment. All rhodolith samples were macerated with liquid nitrogen using sterile technique. The resulting slurry was processed using CTAB buffer with $100 \mathrm{mM}$ of EDTA and the PowerSoil $^{\circ}$ DNA Isolation Kit (MoBio Laboratories, Carlsbad, CA, USA). A purification column was used to recover high-molecular-weight DNA as described by [70].

Water metagenomic libraries were prepared using a XT Nextera DNA sample Preparation Kit (Illumina) $(n=16)$. Rhodolith holobiont libraries were prepared using Accel-NGS 2S DNA Library Kit for Illumina platform (Swift Biosciences) $(n=12)$. The two library preparation kits were used because the NGS 2S kit provides better recovery from samples with low DNA concentrations. Variations between the two kits occur at the extreme GC range only (application note from Swift Biosciences). All metagenomic libraries were sequenced on an Illumina MiSeq (MiSeq Reagent Kit v3) at San Diego State University.

\section{Metagenomic sequence analysis}

Metagenomic sequence reads were quality filtered using the PReprocessing and INformation of Sequences tool, PRINSEQ [71] to remove artificial replicate [72], while low quality sequence reads were trimmed to contain less than 5 bases of a Q-score $\leq 15$ [73]. The quality filtered metagenomes were submitted to the MG-RAST 3.1 server (Metagenomics-Rapid Annotation Using Subsystems Technology) [41]. Post quality-control (QC) sequences were annotated using the (SEED) Subsystems Technology for functional classification [74] and the GenBank (M5 non-redundant) database for taxonomic analyses, similar to previous metagenomic analysis
[28, 35, 75-77]. All BLAST queries were performed with a maximum expected cutoff value of $10^{-5}, 60 \%$ of minimum sequence identity and at least $15 \mathrm{bp}$ alignment length. The MG-RAST server is robust in offering accurate taxonomic assignment to algal holobiont metagenomes comprised by distinguishable contributions between Eukaryotic and Prokaryotic domains, as exemplified in the metagenomic signature of Turfs assemblages, complex environmental algal samples, by Walter and collaborators [32].

Statistical analysis was performed using the Statistical Analysis of Metagenomic Profiles (STAMP v.2.0.0) software [78]. For multiple group comparisons, seawater and rhodolith metagenomes were compared by treatments: algae condition (live versus dead rhodolith) and $p \mathrm{CO}_{2}$ level. The multiple groups were compared by analysis of variance using a Tukey-Kramer post hoc test, and a Bonferroni multiple test correction. Comparisons between two groups were performed with the two-sided Welch's t-test with 95\% confidence intervals calculated by inverting the Welch's test and by using the Bonferroni multiple test correction. In all these cases, $p$-values $<0.05$ were considered statistically significant. A principal component analysis (PCA) was conducted using the R statistical software package to compare the functional grouping based on the SEED subsystems (level 1) [74] of all 28 metagenomes generated in the study.

Multidimensional scaling (MDS) plots were used with the annotated metagenome data to visualize the similarities between the rhodolith microbiome and the microbial profile of seawater in terms of taxonomy structure. Taxonomy structure was determined by comparing the relative abundances of 15 higher-rank bacterial classes, eukaryotic classes and archaeal families, in separate analysis. Groupings depicted by the MDS were based on the Bray-Curtis similarities, using either the statistical package PRIMER 6 (Plymouth Routines In Multivariate Ecological Research) or R. Comparisons over time of percentage changes in the relative abundance of taxa/ functions in any treatment were calculated as $\left(\Delta \mathrm{f} / \mathrm{f}_{\mathrm{d} 1}\right) \times$ 100 , where $\Delta \mathrm{f}=\mathrm{f}_{\mathrm{d} 40}-\mathrm{f}_{\mathrm{d} 1}$ (relative abundance in day 40 - relative abundance in day 1 ).

Changes in bacterial communities between day 1 and day 40 of the experiment were calculated based on Bray-Curtis similarities among each of the rhodolith thallus treatments (i.e. live and dead rhodoliths), and each of the two seawater locations (i.e. water column over the live and dead rhodoliths). Prior to further testing, all Bray-Curtis similarity data were examined for normality by visual examination of probability plots, with the data plotted against a normal distribution [79], and for and equal variances using F-tests. All data were found to satisfy the assumptions of parametric statistics. Following this, differences in Bray Curtis similarities between locations (seawater column versus rhodolith thalli) 
and treatments (live versus dead) were then examined using a 2-way ANOVA, followed by Tukey's post hoc tests on the significant location $\mathrm{x}$ treatment interaction (see Results).

All metagenomes analyzed here are available through MG-RAST under the project "Rhodolith_Calcareous Algae under Ocean Acidification" following the accession numbers as listed in Additional file 1.

\section{Additional files}

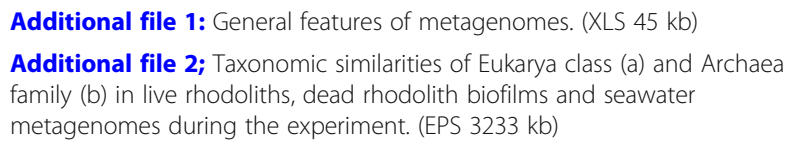

Additional file 3: Relative abundance of bacterial families in Rhodolith (live and dead) metagenomes (1\% > hits contribution). (EPS 4059 kb)

Additional file 4: Functional profile. (a) Rhodolith metabolic profile for both live algae (left column) and dead algae (right column) under ambient air and high $\mathrm{CO}_{2}$ in days 1 and 40. (b) Metabolic profile of seawater tanks for both live treatment (left column) and dead treatment (right column) under ambient air and high $\mathrm{CO}_{2}$ in days 1 and 40. (EPS $7580 \mathrm{~kb}$ )

Additional file 5: Average water chemistry in treatment tanks. (XLS 28 kb)

\begin{abstract}
Abbreviations
$A_{T}$ : Total alkalinity; CCA: Crustose coralline algae; C: Inorganic carbon; MDS: Multidimensional scaling; MG-RAST: Metagenomics-Rapid Annotation Using Subsystems Technology; OA: Ocean acidification; PCA: Principal component analysis; $\mathrm{pCO}_{2}$ : Partial pressure of $\mathrm{CO}_{2} ; \mathrm{P}_{\text {max }}$ : Maximum potential photosynthetic; PRINSEQ: PReprocessing and INformation of Sequences; STAMP: Statistical Analysis of Metagenomic Profiles; T1A: Tank 1 - replicate A, live rhodolith under ambient air treatment; T1B: Tank 1 - replicate $B$, live rhodolith under ambient air treatment; T2A: Tank 2 - replicate $A$, dead rhodolith under high $\mathrm{CO}_{2}$ treatment; T2B: Tank 2 - replicate $\mathrm{B}$, dead rhodolith under high $\mathrm{CO}_{2}$ treatment; T3A: Tank - replicate A, live rhodolith under high $\mathrm{CO}_{2}$ treatment; T3B: Tank - replicate $\mathrm{B}$, live rhodolith under high $\mathrm{CO}_{2}$ treatment; T4A: Tank 4 - replicate $\mathrm{A}$, dead rhodolith under ambient air treatment
\end{abstract}

\section{Acknowledgments}

We would like to thank professor Jean Swings, LM-UGent, Belgium, and visiting professor at Federal University of Rio de Janeiro for generously reviewing the manuscript. We are also grateful to Sean Benler for editing the manuscript. We thank the Coastal and Marine Institute, San Diego State University team for support and maintenance of mesocosm system. This work is part of the Ph.D. thesis of G. Cavalcanti and was developed within the Science Without Borders Program (CNPq, Brazil). We also state no conflict of interest or competing commercial interests in relation to the work.

\section{Funding}

The authors thank CNPq, CAPES, and FAPERJ Brazilian governmental agencies for funding. Funding for the metagenomic sequencing was provided by $E$. Dinsdale by the National Science Foundation Division of Undergraduate Education grant \#1323809 and NSF Division of Microbial Biology grant $\# 1330800$.

\section{Availability of data and materials}

The 28 metagenomes analyzed will be available through MG-RAST server under the project named "Rhodolith_Calcareous Algae under Ocean Acidification" following the accession numbers: 4585168.3, 4585169.3, 4585170.3, 4585171.3, 4585172.3, 4585173.3, 4585174.3, 4585175.3, 4585176.3, 4585177.3, $4585178.3,4585179.3,4585180.3,4585181.3,4585182.3,4585183.3,4587441.3$, 4587442.3, 4587443.3, 4587444.3, 4587445.3, 4587446.3, 4587447.3, 4587448.3, $4587449.3,4587450.3,4587451.3,4587452.3$. All samples are properly identified in Additional file 1.

\section{Authors' contributions}

Study Design: GC, ED, MSE, FLT. Performed experiment: GC, BR, PS, MM. Data Collection: GC, BR, PS, MM, MD, MF. Analyses: GC, MM, PS, MF, MD, CCT, MSE, ED, FLT. Manuscript writing: GC wrote the manuscript and all authors contributed to revisions. All authors have read and approved the manuscript.

Ethics approval and consent to participate

Calcareous Coralline Algae - Rhodoliths were collected and experiments were conducted under the permit from Dr. Matthew Edwards (Coastal Marine Institute - San Diego State University) number SC-751.

\section{Consent for publication}

Not applicable.

\section{Competing interests}

Dr. Fabiano Thompson is a member of the editorial board (Associated Editor) of the BMC Genomics Journal.

\section{Publisher's Note}

Springer Nature remains neutral with regard to jurisdictional claims in published maps and institutional affiliations.

\section{Author details}

${ }^{1}$ Biology Institute, Federal University of Rio de Janeiro (UFRJ), Rio de Janeiro, RJ 21941-599, Brazil. ²Department of Biology, San Diego State University, San Diego, CA 92182, USA.

Received: 3 April 2018 Accepted: 11 September 2018

Published online: 24 September 2018

\section{References}

1. Millero FJ, Graham TB, Huang F, Bustos-Serrano H, Pierrot D. Dissociation constants of carbonic acid in seawater as a function of salinity and temperature. Mar Chem. 2006;100:80-94.

2. Millero F. The marine inorganic carbon cycle. Chem Rev. 2007;107:308-41.

3. Kleypas JA, Buddemeier RW, Archer D, Gattuso J-P, Langdon C, Opdyke BN. Geochemical consequences of increased atmospheric carbon dioxide on coral reefs. Science (80- ). 1999;284:118-20.

4. Orr JC, Fabry VJ, Aumont O, Bopp L, Doney SC, Feely RA, et al. Anthropogenic Ocean acidification over the twenty-first century and its impact on calcifying organisms. Nature. 2005;437:681-866.

5. Reyes-Nivia C, Diaz-Pulido G, Kline D, Guldberg OH, Dove S. Ocean acidification and warming scenarios increase microbioerosion of coral skeletons. Glob Chang Biol. 2013;19:1919-29.

6. Hoegh-Guldberg O, Mumby PJ, Hooten AJ, Steneck RS, Greenfield P, Gomez $\mathrm{E}$, et al. Coral reefs under rapid climate change and ocean acidification. Science (80- ). 2007;318:1737-42.

7. Kroeker KJ, Kordas RL, Crim R, Hendriks IE, Ramajo L, Singh GS, et al. Impacts of ocean acidification on marine organisms: quantifying sensitivities and interaction with warming. Glob Chang Biol. 2013;19:1884-96.

8. Kroeker KJ, Kordas RL, Crim RN, Singh GG. Meta-analysis reveals negative yet variable effects of ocean acidification on marine organisms. Ecol Lett. 2010; 13:1419-34.

9. Johnson MD, Price NN, Smith JE. Contrasting effects of ocean acidification on tropical fleshy and calcareous algae. PeerJ. 2014;2:e411.

10. Riebesell U, Gattuso J-P. Lessons learned from ocean acidification research. Nat Publ Gr. 2015:5:12-4

11. Bischoff WD, Bishop FC, Mackenzie FT. Biogenically produced magnesian calcite: inhomogeneities in chemical and physical properties: comparison with synthetic phases. Am Mineral. 1983;68:1183-8.

12. Bilan MI, Usov Al. Polysaccharides of calcareous algae and their effect on the calcification process. Russ J Bioorganic Chem. 2001;27:2-16.

13. Mccoy SJ, Kamenos NA. Coralline algae (Rhodophyta) in a changing world: integrating ecological, physiological, and geochemical responses to global change. J Phycol. 2015;51:6-24.

14. Ries JB, Cohen AL, McCorkle DC. Marine calcifiers exhibit mixed responses to CO2-induced ocean acidification. Geology. 2009;37:1131-4.

15. Martin S, Gattuso J-P. Response of Mediterranean coralline algae to ocean acidification and elevated temperature. Glob Chang Biol. 2009;15:2089-100.

16. Ragazzola F, Foster LC, Form AU, Buscher J, Hansteen TH, Fietzke J. Phenotypic plasticity of coralline algae in a high CO2 world. Ecol Evol. 2013;3:3436-46. 
17. Mccoy SJ, Ragazzola F. Skeletal trade-offs in coralline algae in response to ocean acidification. Nat Clim Chang. 2014;4:1-5.

18. Büdenbender J, Riebesell U, Form A. Calcification of the Arctic coralline red algae Lithothamnion glaciale in response to elevated CO2. Mar Ecol Prog Ser. 2011:441:79-87.

19. Kamenos NA, Burdett HL, Aloisio E, Findlay HS, Martin S, Longbone C, et al. Coralline algal structure is more sensitive to rate, rather than the magnitude, of ocean acidification. Glob Chang Biol. 2013;19:3621-8.

20. Noisette F, Egilsdottir H, Davoult D, Martin S. Physiological responses of three temperate coralline algae from contrasting habitats to near-future ocean acidification. J Exp Mar Bio Ecol. 2013;448:179-87. https://doi.org/10. 1016/j.jembe.2013.07.006

21. Johnson MD, Moriarty WW, Carpenter RC. Acclimatization of the crustose coralline alga Porolithon onkodes to variable pCO2. PLoS One. 2014;9:e87678.

22. Egilsdottir H, Noisette F, Noël LMLJ, Olafsson J, Martin S. Effects of pCO2 on physiology and skeletal mineralogy in a tidal pool coralline alga Corallina elongata. Mar Biol. 2013;160:2103-12.

23. Hofmann L, Straub S, Bischof K. Competition between calcifying and noncalcifying temperate marine macroalgae under elevated CO2 levels. Mar Ecol Prog Ser. 2012;464:89-105.

24. Amado-Filho GM, Moura RL, Bastos AC, Salgado LT, Sumida PY, Guth AZ, et al. Rhodolith beds are major $\mathrm{CaCO} 3$ bio-factories in the tropical south West Atlantic. PLoS One. 2012;7:e35171.

25. Foster MS. Rhodoliths: between rocks and soft places. J Phycol. 2001;37:659-67.

26. Nelson WA. Calcified macroalgae - critical to coastal ecosystems and vulnerable to change: a review. Mar Freshw Res. 2009;60:787-801.

27. Foster MS, Amado Filho GM, Kamenos NA, Riosmena-Rodriguez R, Steller DL. Rhodoliths and rhodolith beds. Smithson Contrib Mar Sci. 2013;39:143-55.

28. Cavalcanti GS, Gregoracci GB, Dos Santos EO, Silveira CB, Meirelles PM, Longo $L$, et al. Physiologic and metagenomic attributes of the rhodoliths forming the largest CaCO3bed in the South Atlantic Ocean. ISME J. 2014;8: 52-62. https://doi.org/10.1038/ismej.2013.133.

29. Van Der Heijden LH, Kamenos NA. Reviews and syntheses: calculating the global contribution of coralline algae to total carbon burial. Biogeosciences. 2015;12:6429-41.

30. Egan S, Harder T, Burke C, Steinberg P, Kjelleberg S, Thomas T. The seaweed holobiont: understanding seaweed-bacteria interactions. FEMS Microbiol Rev. 2013:37:462-76.

31. Hester ER, Barott KL, Nulton J, Vermeij MJA, Rohwer FL. Stable and sporadic symbiotic communities of coral and algal holobionts. ISME J. 2016;10:1157-69. https://doi.org/10.1038/ismej.2015.190.

32. Walter JM, Tschoeke DA, Meirelles PM, De Oliveira L, Leomil L, Tenório M, et al. Taxonomic and functional metagenomic signature of turfs in the Abrolhos reef system (Brazil). PLoS One. 2016;11:e0161168.

33. Minich JJ, Morris MM, Brown M, Doane M, Edwards MS, Michael TP, et al Elevated temperature drives kelp microbiome dysbiosis, while elevated carbon dioxide induces water microbiome disruption. PLOS ONE. 2018;13(2): e0192772. https://doi.org/10.1371/journal.pone.0192772.

34. Morris MM, Haggerty JM, Papudeshi BN, Vega AA, Edwards MS, Dinsdale EA. Nearshore pelagic microbial community abundance affects recruitment success of giant kelp, Macrocystis pyrifera. Front Microbiol. 2016;7:1800.

35. Minich JJ, Morris M, Brown M, Doane M, Edwards MS, Dinsdale E. Elevated temperature drives kelp microbiome dysbiosis, while elevated carbon dioxide induces water microbiome disruption. PLoS One. 2018;13(2): e0192772.

36. Graham LE, Wilcox LW, Knack JJ. Why we need more algal metagenomes. J Phycol. 2015;51:1029-36.

37. Dittami SM, Duboscq-Bidot L, Perennou M, Gobet A, Corre E, Boyen C, et al. Host-microbe interactions as a driver of acclimation to salinity gradients in brown algal cultures. ISME J. 2016;10:51-63.

38. Dittami SM, Eveillard D, Tonon T. A metabolic approach to study algalbacterial interactions in changing environments. Mol Ecol. 2014;23:1656-60.

39. Webster NS, Negri AP, Flores F, Humphrey C, Soo R, Botté ES, et al. NearFuture Ocean acidification causes differences in microbial associations within diverse coral reef taxa. Environ Microbiol Rep. 2013;5:243-51.

40. Webster NS, Negri AP, Botté ES, Laffy PW, Flores F, Noonan S, et al. Hostassociated coral reef microbes respond to the cumulative pressures of ocean warming and ocean acidification. Sci Rep. 2016;6:19324. https://doi. org/10.1038/srep19324.

41. Meyer F, Paarmann D, D'Souza M, Olson R, Glass EM, Kubal M, et al. The metagenomics RAST server - a public resource for the automatic phylogenetic and functional analysis of metagenomes. BMC Bioinformatics. 2008;9:386.

42. Gattuso JP, Frankignoulle M, Smith SV. Measurement of community metabolism and significance in the coral reef CO2 source-sink debate. Proc Natl Acad Sci U S A. 1999;96:13017-22.

43. Price NN, Hamilton SL, Tootell JS, Smith JE. Species-specific consequences of ocean acidification for the calcareous tropical green algae Halimeda. Mar Ecol Prog Ser. 2011;440:67-78.

44. Martin S, Cohu S, Vignot C, Zimmerman G, Gattuso JP. One-year experiment on the physiological response of the Mediterranean crustose coralline alga, Lithophyllum cabiochae, to elevated pCO2and temperature. Ecol Evol. 2013; 3:676-93.

45. Hurd CL, Hepburn CD, Currie Kl, Raven JA, Hunter KA. Testing the effects of ocean acidification on algal metabolism: considerations for experimental designs. J Phycol. 2009:45:1236-51.

46. Mcconnaughey TA, Whelan JF. Calcification generates protons for nutrient and bicarbonate uptake. Earth-Science Rev. 1997:42:95-117.

47. Hofmann LC, Koch M, De Beer D. Biotic control of surface pH and evidence of light-induced $\mathrm{H}+$ pumping and $\mathrm{Ca} 2+-\mathrm{H}+$ exchange in a tropical crustose coralline alga. PLoS One. 2016;11:e0159057.

48. Hurd CL, Cornwall CE, Currie K, Hepburn CD, McGraw CM, Hunter KA, et al. Metabolically induced pH fluctuations by some coastal calcifiers exceed projected 22nd century ocean acidification: a mechanism for differential susceptibility? Glob Chang Biol. 2011;17:3254-62.

49. Koch M, Bowes G, Ross C, Zhang XH. Climate change and ocean acidification effects on seagrasses and marine macroalgae. Glob Chang Biol. 2013;19:103-32.

50. Borowitzka MA, Larkum AWD. Calcification in algae : mechanisms and the role of metabolism. In: Critical Reviews in Plant Science; 1987. p. 37-41.

51. Johnson MD, Carpenter RC. Ocean acidification and warming decrease calcification in the crustose coralline alga Hydrolithon onkodes and increase susceptibility to grazing. J Exp Mar Bio Ecol. 2012:434-435:94-101. https:// doi.org/10.1016/j.jembe.2012.08.005

52. Comeau S, Carpenter RC, Edmunds PJ. Coral reef calcifiers buffer their response to ocean acidification using both bicarbonate and carbonate. Proc R Soc B. 2012;280:20122374. https://doi.org/10.1098/rspb.2012.2374.

53. Vásquez-Elizondo RM, Enríquez S. Coralline algal physiology is more adversely affected by elevated temperature than reduced pH. Sci Rep. 2016;6:19030.

54. Shukla P, Edwards MS. Elevated pCO2 is less detrimental than increased temperature to early development of the giant kelp, Macrocystis pyrifera (Phaeophyceae, Laminariales). Phycologia. 2017;56:638-48.

55. Webster NS, Reusch TBH. Microbial contributions to the persistence of coral reefs. ISME J. 2017;11:2167-74.

56. Zaneveld JR, McMinds R, Thurber RV. Stress and stability: applying the Anna Karenina principle to animal microbiomes. Nat Microbiol. 2017;2:17121.

57. Mock T, Daines SJ, Geider R, Collins S, Metodiev M, Millar AJ, et al. Bridging the gap between omics and earth system science to better understand how environmental change impacts marine microbes. Glob Chang Biol. 2016;22:61-75.

58. Weiss A, Martindale RC. Crustose coralline algae increased framework and diversity on ancient coral reefs. PLoS One. 2017;12:e0181637.

59. Hernández-kantún JJ, Riosmena-rodriguez R, Hall JM. Phylogenetic analysis of rhodolith formation in the Corallinales ( Rhodophyta ). Eur J Phycol. 2015; 50:46-61.

60. Brown MB, Edwards MS, Kim KY. Effects of climate change on the physiology of giant kelp, Macrocystis pyrifera, and grazing by purple urchin, Strongylocentrotus purpuratus. Algae. 2014;29:203-15.

61. Hurlbert $\mathrm{SH}$. Pseudoreplication and the design of ecological field experiments. Ecol Monogr. 1984;54:187-211.

62. Wernberg T, Smale DA, Thomsen MS. A decade of climate change experiments on marine organisms: procedures, patterns and problems. Glob Chang Biol. 2012; 18:1491-8.

63. Cornwall CE, Hurd CL. Experimental design in ocean acidification research: problems and solutions. ICES J Mar Sci. 2015;73:572-81.

64. Hofmann GE, Smith JE, Johnson KS, Send U, Levin LA, Micheli F, et al. Highfrequency dynamics of ocean $\mathrm{pH}$ : a multi-ecosystem comparison. PLoS One. 2011;6:e28983

65. Millero FJ, Zhang J-Z, Lee K, Campbell DM. Titration alkalinity of seawater. Mar Chem. 1993;44:153-65.

66. Lewis E, Wallace D. Program Developed for CO2 system calcaulations, Ornl/ Cdiac-105; 1998. p. 1-21. 
67. Tompkins PA. Distribution, growth, and disturbance of Catalina Island rhodoliths. 2011.

68. Platt T, Denman KL, Jassby AD. The mathematical representation and prediction of Phytoplankton Productivity. Fish Mar Serv. 1975:513:110.

69. Price NN, Martz TR, Brainard RE, Smith JE. Diel variability in seawater pH relates to calcification and benthic community structure on coral reefs. PLoS One. 2012;7:e43843.

70. Garcia GD, Gregoracci GB, de O Santos E, Meirelles PM, Silva GGZ, Edwards $R$, et al. Metagenomic analysis of healthy and white plague-affected Mussismilia braziliensis corals. Microb Ecol. 2013;65:1076-86.

71. Schmieder R, Edwards R. Quality control and preprocessing of metagenomic datasets. Bioinformatics. 2011;27:863-4.

72. Gomez-Alvarez V, Teal TK, Schmidt TM. Systematic artifacts in metagenomes from complex microbial communities. ISME J. 2009;3:1314-7. https://doi. org/10.1038/ismej.2009.72.

73. Cox MP, Peterson DA, Biggs PJ. SolexaQA: at-a-glance quality assessment of Illumina second-generation sequencing data. BMC Bioinformatics. 2010;11:485.

74. Overbeek R, Begley T, Butler RM, Choudhuri JV, Chuang H-Y, Cohoon M, et al. The subsystems approach to genome annotation and its use in the project to annotate 1000 genomes. Nucleic Acids Res. 2005;33:5691-702.

75. Haggerty JM, Dinsdale EA. Distinct biogeographical patterns of marine bacterial taxonomy and functional genes. Glob Ecol Biogeogr. 2017;26:177-90.

76. Dinsdale EA, Edwards RA, Bailey BA, Tuba I, Akhter S, Mcnair K, et al. Multivariate analysis of functional metagenomes. Front Genet. 2013:4:41.

77. Dinsdale EA, Edwards RA, Hall D, Angly F, Breitbart M, Brulc JM, et al. Functional metagenomic profiling of nine biomes. Nature. 2008;452:629-32.

78. Parks DH, Beiko RG. Identifying biologically relevant differences between metagenomic communities. Bioinformatics. 2010;26:715-21.

79. Chambers JM, Cleveland WS, Kleiner B, Tukey PA. Graphical methods for data analysis. Wadsworth: Wadsworth international group; 1983.

Ready to submit your research? Choose BMC and benefit from:

- fast, convenient online submission

- thorough peer review by experienced researchers in your field

- rapid publication on acceptance

- support for research data, including large and complex data types

- gold Open Access which fosters wider collaboration and increased citations

- maximum visibility for your research: over $100 \mathrm{M}$ website views per year

At BMC, research is always in progress.

Learn more biomedcentral.com/submissions 